\title{
Surveys of the use of information and Communications technologies by community- based organisations
}

\author{
Tom Denison, \\ Graeme Johanson
}

Centre for Community Networking Research

Faculty of Information Technology, Monash University.

\begin{abstract}
This paper looks to fill an international gap in knowledge about the adoption of information and communication technologies by third sector organisations with a specific focus on the Australian experience. In Australia, the United Kingdom, USA, and Canada, such research that exists into the usefulness of the spread of ICT into community-based organisations, is limited in its coverage and its tendency is to rely on a management approach to analysis. This paper summarises findings of recently published surveys, compares their findings, and proposes the use of social network analysis as a more useful lens through which to consider current developments.
\end{abstract}

\section{Prologue}

The original research for this article was undertaken in early 2005, and since then there have been two substantive developments with findings to be added to the review. Firstly, very soon after this article was first written a refreshing interest in Australia encompassing the spread of ICT in the third sector emerged from within the sector itself, but also from governments wishing to deal with community-based organisations. The second relates to the worldwide fascination with Web 2.0 technologies and associated attention devoted to social technologies (Marks 2006). From the standpoint of September 2007, some of the research wish-list outlined in the Conclusions to this article is being fulfilled in relation to co-ordination and whole-of-sector networks.

In February 2005 the Australian Department for Communications, Information Technology and the Arts (DCITA) released two discussion papers on the impact of ICT on the Australian non-profit sector and the importance of the sector in building communities (DCITA 2005a; 2005b). These papers aimed to illustrate how non-profit organisations and communities were using ICT to improve operational efficiency and capability; deliver services and support; and build communities and social capital. DCITA responded by initiating a project to develop a model and business plan for a National Non-profit ICT Coalition (NNIC), conceived of as a coalition of leading non-profit organisations and social enterprises (DCITA 2005c). Ideally, this would assist the sector in making more effective use of ICT by providing strategic leadership for the Australian non-profit sector; raising the awareness of the strategic benefits of ICT; improving the understanding of senior staff of non-profit organisations; facilitating the development of sustainable models for non-profit organisations; improving the ICT infrastructure, funding and procurement for non-profit organisations; and increasing engagement between the business and non-profit sectors.

In 2006 a contract to manage the project was awarded to a consortium led by Community Information Strategies Australia Inc (CISA) - a community-based not-for-profit organisation that provides a range of (ICT) consulting services. Members of the consortium selected included the Centre for Community Networking Research (CCNR) at Monash University, WorkVentures Australia, Albany Consulting, Energetica Consulting, and the Non-profit Roundtable, a group of major non-profit representatives. After six months of intensive research (Denison et al. 2007), the key findings of the consultation were that there 
is a recognition that the application of ICT has enormous potential not only to contribute to administrative efficiency, but also to transform service delivery in the third sector. As well, and unfortunately it was found that this potential is not being realised because the sector lacks a coordinated approach to the adoption of ICT, which impacts on its ability to contribute to policy development, standards setting, and a range of other activities that could share and reduce the costs of adopting ICT. The study further found that at the level of the individual organisation, there are considerable problems caused by an inability to think strategically, a widespread lack of skills and resources, a lack of funding, and few available trusted sources of advice. The research revealed very strong support for a NNIC-type organisation, which would function in its own right rather than as part of any existing peak body; be led by the sector; would not become a service provider in its own right; and would avoid fee-based membership because such funding would act as a disincentive to smaller organisations.

These recent developments do not invalidate the key points of the remainder of this article, but they indicate that constructive action has been occurring recently.

\section{Surprising dearth of surveys}

With access to the Internet by Australian businesses running at $74 \%$ of all businesses (ABS 2005), and egovernment widespread, now reaching deep into the layers of local government (ABS 2004), the absence of detailed collated data about the use of information and communication technologies in the third sector is an unfortunate gap. It is not just a problem in Australia: lack of reliable knowledge poses a constraint for policy and planning in the sector across the developed world.

The voluntary sector is under many pressures to change (Lyons 2001, Surman 2001, Burt and Taylor 1999). There is evidence that many community-based organisations are using information and communications technologies (ICT) to improve their functions and status, yet the means to determine the broad scope of their activity does not exist. The Canadian Government's Panel on Accountability and Governance in the Voluntary Sector attributes low levels of adoption to recent change, in the following terms:

In recent years, the voluntary sector's infrastructure has been significantly weakened for a number of reasons. As a result of government cuts to funding, often combined with downloading onto the sector of services once provided by governments, there is intense competition for funds, not only within the sector but often with governments directly. The pressure to deliver more and more sophisticated services has stretched the financial and human resources of many organisations. Information technology has become an essential tool for effective communication and management in the modern organisation, yet voluntary organisations lag badly behind the other sectors in this regard (Voluntary Sector Initiative 1999, p. 14).

Thus a reason for lack of understanding of the penetration of ICT is intimated; the sector is so pressured to involve itself with adoption and adaptation of technologies that it has not had the resources to reflect on the implementation. The literature contains numerous examples of efforts to make partial amends. For example, an early study (ACOSS 1996) into the use of ICT by Australian community sector organisations found that many were developing their ICT capacity with the aim of entering into a partnership with government for the provision of community services and, increasingly, that has meant facing up to economies of scale. Understandably, they did 'not want to be marginalised because they [were] not staying current' (PRA 2001, p. 9).

Using information drawn from publications in the USA, the UK, Canada and Australia, this paper examines several recently published surveys dealing with the rate of take-up of ICT by community sector organisations. In particular, it focuses on the use of the Internet by non-profit organisations, and their own reported judgements in areas related to the success or failure of that take-up, the reported barriers faced by the sector, and what important aspects of involvement with ICT are apparently not at all being addressed. It will then briefly consider the published summaries from the perspective of social network analysis, particularly as it relates to the diffusion of technology, to consider whether it might lead to new insights or prospects for further research. 


\section{Parameters of existing knowledge}

Even a cursory examination of the literature reveals the looseness of relevant terminology. It varies from country to country, and includes such terms as 'voluntary organisations', 'non-profits', 'non-government organisations' (NGOs), 'community organisations' and 'charities'. At the sectoral level the organisations attract a set of related names -- the 'voluntary sector', the 'third sector', the 'non-profit sector,' even 'civil society'. Use of so many terms can create confusion. For instance, this paper has excluded the specific use of ICT for civic engagement, for political activism, a topic which has attracted a good deal more separate interest from political scientists and sociologists - under the banner of civil society uses of ICT -- than have any accounts of benefits of ICT for the all-encompassing aims and objectives of all community-based organisations (see, for example, Barraket 2005).

While more specific terminology is applied within individual countries (National Centre for Charitable Statistics 2004, Kendall 1995, Lyons 2001), the locus of activity is not easily defined. Typical is the Canadian Government's Panel on Accountability and Governance in the Voluntary Sector (1999) which considers

organisations whose work depends on serving a public benefit: on volunteers, at least for their governance; on financial support from individuals; and on limited direct influence by governments (Voluntary Sector Initiative 1999, p. 9).

This includes recreational associations, service clubs, local community associations, advocacy groups, and community development groups.

There are limitations to what this paper can achieve, as is acknowledged in the ensuing discussion. A detailed analysis of the differences between ICT needs in the business, government and community sectors is beyond the scope of this paper, though it would be instructive to undertake at a later date. Making comparisons between countries, as we do, runs the risk of ignoring potential structural differences, for example in the consideration of issues posed by location, national reach versus geographic spread, the firmness of boundaries between organisations, and globalised NGOs.

What are the reasons given by those conducting studies to propose that the encouragement of the take-up of ICT by community organisations is worthwhile? The business analogy is never far away. The key motivation remains the benefit to the organisations and their members or clients. As Burt and Taylor (1999, p. 8) state:

Electronic networking allows the innovative potential of ICT to be exploited, including its capacity to support flexible forms of organisational and business relationships ... ICT allow managers to interrogate information systems in new ways, to integrate across their organisation, information that was previously unconnected, to ask new questions about their organisation and its relationship with clients, members, supporters, partners and competitors.

Thus, it can contribute to competitive positioning, and so to the achievement of mission, and strategic and business objectives.

Much of the research, however, is concerned with broader relationships. For example, Surman (2001) is interested not only with the immediate needs of Ontario non-profits, exploring questions such as current voluntary sector technological capacity, Internet services and available funding, but also with evidence that suggests that the voluntary sector as a whole is being transformed into a connected, co-operative network.

Others focus on the broader societal issues and the function of organisations in context. The work of the Canadian Voluntary Sector Initiative (1999) sought to improve the performance of the sector not just because the organisations themselves would benefit, but also because it saw the voluntary sector as playing a central role in building vibrant communities, providing services and engaging citizens in the democratic life of the country. It also recognised that the voluntary sector makes an enormous contribution to the country's economic well-being.

These themes are central also to the work of the Athena Alliance (2002) and Craig (2003), who focus on the ability of organisations to contribute to a reduction in the digital divide by providing services and access to the disadvantaged. Craig (2003) comments that the third sector is important to community ICT because 
organisations may provide ICT access centres for their clients, who are often disadvantaged in several ways...; organisations can improve the delivery of their core services to the disadvantaged...; and by becoming more skilled themselves in ICT, these groups can leverage their knowledge of their clients needs to help them pass on relevant ICT skills and knowledge (Craig 2003, p63).

O'Donnell, analysing the situation in Ireland $(1997,1999)$ and in the European Union (2001), advances this argument even further, considering that the voluntary sector has a significant part to play in fostering a more inclusive information society through its ability to expand online content and the public sphere. Implicit advocacy by means of ICT is an indirect asset which we return to in our discussion of the surveys, which we now summarise.

\section{Major survey findings}

\section{United Kingdom}

The situation in the UK has been well described by major national surveys undertaken by Burt and Taylor (1999) and Wyatt (2001), both of whom focused on the uptake of ICT and its contribution to meeting the business needs of community organisations, while TBC Research (2001) surveyed those already using ICT more generally.

Although TBC Research (2001) reported that $82 \%$ of organisations that were already using ICT had established websites, the two surveys of all community organisations, those of Burt and Taylor (1999) and Wyatt (2001), reported a less than satisfactory picture. These found that there was almost universal access to personal computers and high levels of computer networking, but that the take-up level of key technologies and applications such as websites was significantly lower. Wyatt compared progress to that of the business sector, reporting that by the end of $2001,78 \%$ of community organisations expect to have an Internet connection, compared to $94 \%$ of businesses, while $53 \%$ expect to have a web page, compared to $80 \%$ of businesses.

On the other hand, Wyatt (2001) also found that benefits in delivering services via the Internet were claimed by organisations across the voluntary and community sectors, and that a number of organisations were delivering services in new and more effective ways, especially those which deal with people with disabilities and job seekers. He found that some organisations were improving their inter-organisational networking - developing new ways of working together and exchanging experiences of best practice, which previously had been excessively costly and time-consuming. Despite these positive findings, all the UK studies concluded that the impact of ICT was less than its potential, and that the application of technology to key business activities was poor, with few organisations having made strategic use of the technology, for example, by sharing information with stakeholders or improving service delivery. Wyatt added that the overall extent of ICT infrastructure in the sector was poor.

Other barriers to the further development of the sector included: the cost of equipment and maintenance (Wyatt, TBC Research); negative attitudes to ICT and limited appreciation of its benefits, particularly by senior management and management boards (Wyatt, Burt and Taylor, TBC Research); a lack of support and training (Wyatt, Burt and Taylor, TBC Research); insufficient project management skills (TBC Research); and insufficient access to relevant experts (TBC Research). All reported that budgets were too small for their needs, yet none of the surveys reported the size of the organisation to be an issue.

\section{United States}

A number of studies have been conducted in the USA, but there is little on a broad scale, and the national picture remains obscure. Significant studies include those of Williams (1999) who surveyed Michigan nonprofits, and Princeton Research Associates (2001) and the W. K. Kellogg Foundation (2001), both of which undertook broader surveys. The Center for Excellence in Non-profits (1999) did undertake a major survey of Silicon Valley non-profits in 1998, but that study focused on in-house networking and applications only.

Of these, Williams (1999) reported that while $77 \%$ of surveyed organisations had access to the Internet on site, only $52 \%$ had websites and that the proportion using e-mail varied from $60 \%$ of small organisations (revenue of less than $\$ 50,000$ ) to $94 \%$ of those with revenues of $\$ 2 \mathrm{~m}$ or more. Princeton Research 
Associates (2001) reported that 79\% use e-mail, 77\% use the Internet and $49 \%$ have a website while the Kellogg Foundation (2001) reported that $75 \%$ had websites. However it should be noted that the Kellogg Foundation survey was conducted by e-mail and so presumably was biased towards those already using the technology.

Even though the actual results are not widely different from those reported by the UK surveys, the overall reported attitude of US not-for-profits is more positive. For example, Princeton Research Associates found that

sizeable majorities believe increased use of IT would improve the efficiencies of their day-to-day operations, improve communication with staff and constituents, enhance their profile and presence in the community, and ultimately save money by increasing efficiency (2001, p. 3)

While Williams (1999) found that $45 \%$ of organisations surveyed agreed with the statement that 'Michigan non-profits are ready for the information age' and 58\% agreed with the statement that 'the Internet is improving non-profit marketing and product/service delivery'.

Unlike in the UK, the most common reason reported for not taking up the technologies in the USA was that they were either not needed, or that the acquisition of other resources had a higher priority. Cost and access to appropriate staff were still reported as problems by those who had taken them up, and size was an issue for smaller non-profits (Princeton Research Associates 2001).

\section{Canada}

The use of ICT by community sector organisations has been widely encouraged in Canada, with the Government having been particularly active. Following on from the work of the Broadbent Report, the work of VolNet and the Joint Table on Information Management/Information Technology has been important in both establishing the existing situation and in proposing strategies to move forward (Voluntary Sector Initiative 1999, Voluntary Sector 2002, PRA 2001, Kerr 2002). Major surveys of organisations using the Web have also been undertaken by Leverus (2001; 2002), and both Pargmegiani and Sachdeva (2000) and Surman (2001) have made significant comparative studies of existing surveys, the latter combining a review of websites serving non-profits in the Ontario region, with an overview of significant available surveys from Canada, the USA and the UK.

Surprisingly, for a country as involved in community building projects as Canada, there is little published on actual take-up rates of ICT. Surman does quote one result provided by the Canadian Centre for Philanthropy - that $37 \%$ of Canadian voluntary organisations had Internet access by 1997 -- but on the whole the work in Canada seems more concerned with what organisations are doing with ICT internally, and the barriers which they might face.

Although Pargmegiani and Sachdeva (2000) drew the broad conclusion that Canada was a world leader in Internet usage, especially in publicly funded programs supporting the voluntary sector, there were clearly limited achievements. Surman, focusing on the Ontario region, concluded that the foundation had been laid for the 'transformation of the voluntary sector into a connected co-operative network' (2001, p. 3), but that the tools and techniques required for this to happen had not spread widely. Organisations using the Internet to address core non-profit business needs such as fundraising, volunteer recruitment, information sharing and reporting to government, were the exceptions rather than the rule. The annual Leverus surveys suggest that there have been advances in the range of uses, and the ability of organisations to leverage the potential of the Internet, but that there remain significant areas in need of improvement, including strategic planning and ongoing analysis of performance. For example, the Leverus survey reported that while $54 \%$ of organisations think that their website is effective or very effective in contributing to their ability to meet their organisational objectives, $46 \%$ think that their websites are only somewhat effective or have no effect at all (Leverus 2001).

Both PRA (2001) and Surman (2001) concluded that the sector had three main needs: access to unbiased knowledge about what technologies to purchase; increased technology skills and knowledge within the sector; and a better understanding of technology needs by funders. PRA also concluded that the capacity of organisations to successfully adopt ICT was affected by the availability of technical staff, the size of the organisation and access to resources; and depended on the culture of the organisation and degree of comfort with technology felt by leaders. 
Taking a different approach, Kerr (2002) attempted to identify the needs and priorities of the sector in relation to technology, and to suggest options for potential funding. The top five needs put forward by the organisations were: an inexpensive and easy-to-use database of funders; direct funding at discounted prices of computers and related items; more flexibility from funders to allow organisations to buy computers and software or upgrades, as an ongoing expense; reduced administration and paperwork for filling out funding proposals and reports; and a national website that would provide 'one-stop shopping' for information for and about the voluntary sector.

\section{Australia}

There are three major surveys in Australia -- by ACOSS (1996), VCOSS (1997) and CCNR (2002). In terms of Internet take-up, the two earlier surveys (ACOSS 1996, VCOSS 1997) confirmed limited but growing support for the medium within the sector, with almost universal access to some level of computing. ACOSS reported that $38 \%$ were connected to the Internet and that $14 \%$ had a website, while VCOSS reported that $59 \%$ had access to the Internet and $17 \%$ had websites. The CCNR ICT Index (2002), 5 years later, confirmed those early trends in terms of the rapid take-up of ICT, reporting that the proportion of community-based organisations with access to the Internet increased to $90 \%$ and that the proportion with websites had risen to $61 \%$.

CCNR found that city-based organisations would appear to be better at taking advantage of the medium, and while the use of sites to collect information and to conduct financial transactions register as significant differences between city-based and regional organisations, in fact most organisations put their sites to a fairly limited range of uses. VCOSS reported that, despite a variety of reported uses, just under $50 \%$ of organisations had unmet needs for online services. CCNR found high levels of satisfaction with the performance of the technology in general and with their Internet access, but that only $56 \%$ of organisations with websites agreed that those websites were meeting their needs. Examining the data in more detail, Denison (2003) found that location and size, when taken together, also provide a significant indicator of an organisation's level of satisfaction with the ability of the technology to meet its needs, with approximately $44 \%$ of large city-based organisations believing they had a website that met their objectives, while only $22 \%$ of smaller regional organisations made the same claim.

The two early surveys reported that the most significant barriers related to cost to the organisation, followed by the cost to members and clients, while less significant barriers and problems included access difficulties for users, lack of relevant information and/or training for staff, and lack of staff time. Low staff interest or priority was found to be the least significant problem (ACOSS 1996, VCOSS 1997). CCNR reported a similar range of issues, with the most significant being lack of skills, cost to the organisation and organisational priorities, reflecting needs emerging with the continuing spread of ICT use. Once again, the result obtained when the factors of size and location are combined was revealing: small regional organisations were least likely to have a website and lack of relevance to the organisation's needs was found to be the major factor, while for small city-based organisations, it was the cost that was most important (CCNR 2002).

\section{Additional related surveys}

Several other interesting surveys are also available. Zwielko (1998) attempted a study of non-profit environmental organisations across 10 countries and although he attempted to gauge the take-up of access to the Internet and determine if there were any changed patterns of behaviour, policy or politicisation, he did not attempt any inter-country comparisons. His findings showed that of 135 respondent organisations, $68 \%$ were online (by which he meant that they could at least access the Net). $71 \%$ of those were using the Web to provide information and undertake a range of other tasks. He found the main barriers to be cost, lack of expertise, and reluctance on the part of senior staff to use it.

Murray and Harrison (2002) took yet another approach and, instead of surveying organisations in general, focused on those that use technology to meet a particular need or provide a specific service, in this case to help with managing volunteers. In two surveys (one regional, and one national in Canada) they found that most organisations involved in managing volunteers do use technology and that most think that they could make more and better use of technology. Specifically, they found that most use the technology to provide information, and although some attempted to provide a level of interactivity, very few could be considered 
to be attempting to improve communication networks within the sector. They also found that newer managers are more likely to accept such innovations and are less likely to be critical of the performance of the nominated innovation.

Ticher (2002) interviewed executives from some 30 voluntary and community sector organisations in the UK, coming to the conclusion that the biggest barriers to effective use were internal: difficulty in finding reliable, trustworthy professional advice; difficulty in securing internal technical expertise; difficulty in finding affordable external technical expertise; difficulty with project management techniques; and the unwillingness of many funders to accept realistic levels of ICT expenditure. This report also discussed the pace of change management, and the fact that many managers were reluctant to push through changes derived from new technology, as they recognised that some people, including frontline caregivers, may need to be protected from change, and others may resist it. He concluded that managers need a vision about what their organisation might be doing with ICT and the confidence and determination to take ideas forward.

Given the comments found in many of the above surveys, the report by the Technology Affinity Group (2003) on the state of ICT use by grant-makers in the USA is also of interest. While the results showed that the adoption and effective use of technology varied greatly according to the size of the grant-making body, as a group they clearly make good use of it. $95 \%$ of very large foundations responding described themselves as leading-edge or fast followers, with 5\% as lagging or in trouble. That figure rose to $34 \%$ for small foundations (with less than $\$ 10,000,000$ in assets). Perhaps more significantly, while e-mail and websites were common applications, most respondents $(65 \%)$ had no IT staff, only $18 \%$ participated in providing technical assistance and advice to grantees, and only $17 \%$ had IT staff that took part in reviewing applications. 
Table 1. Summary of recent surveys: Community sector organisation use of ICT

\begin{tabular}{|c|c|c|c|c|}
\hline Survey & Year & Country & Method / Sample & Notes \\
\hline Burt \& Taylor & 1999 & UK & $\begin{array}{l}\text { Email. } 436 \text { responses } \\
\text { Non-profit } \\
\text { organisations }\end{array}$ & $\begin{array}{l}\text { Found widespread access to } \\
\text { ICT but poor rates of take-up } \\
\text { and exploitation of websites. }\end{array}$ \\
\hline TBC Research & 2001 & UK & $\begin{array}{l}\text { Voluntary } \\
\text { organizations }\end{array}$ & $\begin{array}{l}\text { Found widespread access to } \\
\text { ICT but lack of access to } \\
\text { strategic advice and significant } \\
\text { concerns relating to the use of } \\
\text { ICT in meeting oraganisational } \\
\text { goals. }\end{array}$ \\
\hline Wyatt & 2001 & UK & $\begin{array}{l}\text { Telephone. } 1400 \\
\text { responses. } \\
\text { Email. } 460 \text { responses } \\
\begin{array}{l}\text { Non-profit } \\
\text { organisations }\end{array}\end{array}$ & $\begin{array}{l}\text { Found almost universal access } \\
\text { to ICT but the levels of take-up } \\
\text { and effective use of key } \\
\text { technologies, specifically } \\
\text { websites, was significantly } \\
\text { lower. }\end{array}$ \\
\hline $\begin{array}{l}\text { Princeton } \\
\text { Research } \\
\text { Associates }\end{array}$ & 2001 & USA & $\begin{array}{l}\text { Telephone. } 203 \text { human } \\
\text { service organizations }\end{array}$ & $\begin{array}{l}\text { Generally very positive, with } \\
\text { respondents suggesting that the } \\
\text { use of ICT is creating } \\
\text { efficiencies and improving } \\
\text { communications. }\end{array}$ \\
\hline Williams & 1999 & $\begin{array}{l}\text { USA } \\
\text { (Michigan) }\end{array}$ & $\begin{array}{l}\text { Mail. } 635 \text { responses } \\
\text { Non-profit } \\
\text { organisations }\end{array}$ & $\begin{array}{l}\text { Found high levels of take-up of } \\
\text { ICT and generally positive } \\
\text { feedback on its benefits. }\end{array}$ \\
\hline W.K. Kellog & 2001 & USA & $\begin{array}{l}\text { Email. } 418 \text { non-profit } \\
\text { organizations }\end{array}$ & $\begin{array}{l}\text { Examined use of websites, } \\
\text { finding organisations were } \\
\text { generally positive about the } \\
\text { benefits they brought: } \\
\text { operational efficiencies and } \\
\text { improved communications }\end{array}$ \\
\hline Leverus & 2001 & Canada & 170 responses & $\begin{array}{l}\text { Surveyed those with websites } \\
\text { and found that although use is } \\
\text { growing there remain }\end{array}$ \\
\hline
\end{tabular}




\begin{tabular}{|l|l|l|l|l|} 
& 2002 & & 218 responses & $\begin{array}{l}\text { significant difficulties in the } \\
\text { area of strategic planning and } \\
\text { analysis of performance. } \\
\text { non-profit } \\
\text { organizations }\end{array}$ \\
\hline PRA & 2001 & Canada & $\begin{array}{l}\text { In-depth interviews } \\
\text { 24 voluntary } \\
\text { organizations }\end{array}$ & $\begin{array}{l}\text { Found a consistent view that } \\
\text { ICT was important to the sector } \\
\text { but that there were a number of } \\
\text { barriers to its effective use, with } \\
\text { cost and access to expertise } \\
\text { being the most significant. }\end{array}$ \\
\hline ACOSS & 1996 & Australia & $\begin{array}{l}\text { Mail. 209 social } \\
\text { service organizations }\end{array}$ & $\begin{array}{l}\text { Found widespread take-up of } \\
\text { ICT, often to meet external } \\
\text { pressures, with the exception of } \\
\text { websites. }\end{array}$ \\
\hline CCNR CICT & 2002 & Australia & $\begin{array}{l}\text { Telephone. 923 non- } \\
\text { profit organizations }\end{array}$ & $\begin{array}{l}\text { Found widespread take-up and } \\
\text { satisfaction with ICT, but } \\
\text { significantly lower rates of } \\
\text { take-up for websites, } \\
\text { particularly in regional areas. }\end{array}$ \\
\hline VCOSS & 1997 & $\begin{array}{l}\text { Australia } \\
\text { (Victoria) }\end{array}$ & $\begin{array}{l}\text { Mail. 323 social } \\
\text { service organizations }\end{array}$ & $\begin{array}{l}\text { Found widespread take-up of } \\
\text { ICT but significant levels of } \\
\text { unmet demand in developing } \\
\text { online services. }\end{array}$ \\
\hline
\end{tabular}




\section{Challenges}

Ticher (2002) considers there to be three traditional stages in ICT use by voluntary organisations: personal productivity, information sharing, and inter-networking. While the research quoted above is not concerned directly with the first two stages, it does relate to the third: inter-networking. Surman (2001) expands this stage into: basic Internet access, knowledge and skills development (strategic and technical), and the development of strategic business applications. Reviewing the situation in the USA, Canada and the UK, he concludes that, except for some rural areas, basic Internet connection and access issues are no longer a major issue for most voluntary organisations and, where data is available, it does suggest that access is increasing overall.

If connectivity itself is not a problem, an analysis of the surveys mentioned demonstrates that, with the possible exception of the USA, the development of strategic business applications is a gap, and this is despite the fact that almost all of those conducting the studies are both positive about the potential benefits and cite numerous examples of organisations which have developed innovative applications and are reaping the rewards.

As can be seen from the discussion, a lot of information has been collected regarding the barriers to effective use of ICT (including the development of websites). Barriers include cost to the organisation, cost to the members or clients of the organisation, a general lack of resources, sources of reliable and independent advice (internal and external), poor attitudes to ICT, a lack of support and training, unwillingness of funders to accept a reliable level of ICT expenditure, unfamiliarity with project planning, and a lack of simple online tools for non-profits.

Given Canada's high level of government activity in supporting non-governmental groups, it is perhaps most useful to cite Canada as an example of the type of strategies developed to cope with ICT weaknesses. The Canadian Joint Table on IM/IT (Voluntary Sector 2002) grouped these challenges under six main headings:

- Diversity of the voluntary sector.

- Limited familiarity of board members, staff and volunteers with information management and information technology.

- Barriers to acquiring information management and information technology.

- Challenge in finding funding.

- Limited means for organisations to communicate and network.

- Sustainability of efforts to make effective use of information management and information technology.

It then adopted a strategy for improvement based on the needs identified by Kerr (2002): encouraging funders to support investment in technology and developing a web-based funding service; linking existing community-based networks to increase regional capacity and provide a virtual technology store; developing a campaign to highlight the benefits of technology; and developing a portal for the voluntary sector as a whole (Voluntary Sector Initiative 2002).

Unobserved benefits of prior networks and environment

Having an understanding of the broad condition of the sector is important because it sets the context for more detailed studies. But, as Cuiker (2003) notes, survey results such as these can only offer basic summaries, and provide limited insights into what is actually happening in given organisations. One move towards improvement would come from supplementing such surveys with qualitative work, such as that undertaken by Schneider (2003), who has used an ethnographic study to explore how issues such as social capital, cultural factors and ICT interact.

Time and again, the analyses considered conclude that limited appreciation of the benefits of ICT, particularly by senior management and management boards (Wyatt, Burt and Taylor, TBC Research), and insufficient access to experts (TBC Research), were serious problems. For example, in Canada, both PRA (2001) and Surman (2001) concluded that the sector had three main needs: access to unbiased knowledge 
about what technologies to purchase, increased technology skills and knowledge within the sector, and a better understanding of technology needs by funders.

And, in general, these problems are being described in terms of failures of management or as being related to issues such as the size and location of organisations. Overall, there is evidence within these analyses that several important considerations - certainly the development of strategies, and the ongoing sustainability of organisations - have not attracted sufficient attention. Nor have other considerations, such as cultural and environmental factors that impact on the diffusion of technology, including 'economic, political and social forces in interplay with technological developments and historical context' which, in combination with management, resource and issues relating to organisational culture, determine the extent to which not for profit organisations are likely to use ICT for innovation and strategic positioning (Burt and Taylor 1999, p. $6)$.

From this perspective it is interesting to note that several studies, including that of Burt and Taylor (1999), make the point that some organisations are improving their inter-organisational networking by 'developing new ways of working together and exchanging best practice that was previously too costly and time consuming,' without considering whether those organisations were already well developed in this area beforehand, and whether or not they succeeded because of this prior inter-networking. In other words, their basic existing levels of inter-networking may not only have contributed to their desire to improve that internetworking, but may also have facilitated that outcome. This vital point has been overlooked in most of the surveys discussed in this paper.

And it is a crucial point. There is a significant body of work in the area of social network analysis that explores the types of social networks and inter-networking arrangements that assist in both the diffusion of technology and its ongoing exploitation. Granovetter (1973) made the distinction between strong and weak links, based on the frequency and distance between people or organisations, arguing that those with networks of weak links are best placed to receive new information and resources, since those links can act as bridges to the broader community. He also found that the more links required to establish a connection, the less effective it is. Others have built on this, demonstrating that networks of strong links are essential for the proper exploitation of new ideas, such as new technology, but that networks of weak links are also essential because it is those networks that provide access to new ideas and resources in the first place (Coleman 1988, Burt 2000, Aldrich \& Zimmer 1986, Kadushin 2002). Further, Aldrich and Zimmer (1986) emphasised that the maintenance of effective networks requires the continual creation of weak ties so as to prevent a few strong ties from closing those networks to opportunities and alternatives, while Kadushin (2002) argued that 'safety drivers', which act against change, are common when the costs of interaction are low, visibility is high, and moral obligations are more salient - a situation typical of rural and regional networks but also common elsewhere. In summary, this analysis suggests that organisations and communities seeking to implement technologically-based change, require both networks of weak links, because they provide access to opportunities, innovation, strategic advice, new skills and support; and networks of strong links because they provide a trusted environment in which to operate and harness local capacity.

There is sufficient evidence to suggest that these factors need to be taken into account when developing strategies to assist those organisations in developing strategic applications, such as websites. The surveys and analyses discussed in this paper do not bring that out sufficiently. Further research into how this applies to community sector organisations is needed but, if it is assumed that most of the organisations surveyed are reasonably managed and embedded in their communities, then the problem that they face in attempting to develop more sophisticated ICT applications such as websites is not one of a lack of management skill, so much as one of not having support networks that can assist them in reacting to new circumstances and in the adoption of technology. This would suggest that what government needs to do is to find ways of working with organisations to build on their strengths while at the same time, in networking terms, provide them with access to trusted weak links that can provide them with access to expertise and other resources. This can perhaps best be achieved by building local capacity and expertise and by fostering trusted local intermediaries. Furthermore, such support needs to be provided on an ongoing basis, because technology and applications are continually changing and advances need to be continually monitored, evaluated and adapted. 


\section{Conclusions}

Surveys of the take-up and use of ICT by community sector organisations are valuable, but they are limited in that they can only provide a generalised picture which is most useful as background to further in-depth studies. Too often their analysis is restricted to a strict managerial approach to the organisations concerned.

To return to an earlier comment that many see improved use of ICT by community sector organisations as a way of improving inter-organisational networking, even a brief consideration of social network analysis would suggest that it is a two-way process, and that those who already have strong networks in place are more likely to find it easier to implement ICT in the first place. This is a more constructive view than that which assumes that problems are caused by management failure or issues related to location and size, because it points the way to developing strategies appropriate to dealing with the real problems. However, to better understand what is actually happening, further research is needed. The nature of networked interactions in relation to community sector organisations needs to be researched systematically, as does the role of networks in facilitating the development of organisational strategies and initiatives. A greater understanding of these processes should not only assist organisations in their take-up of technology but, by focusing on the ways in which organisations obtain skills and resources, contribute to their ongoing sustainability.

\section{References}

Athena Alliance (2002) Extending the information revolution: A white paper on policies for prosperity and security.www.athenaalliance.org (accessed 13/10/04).

ACOSS (1996). Electronic Communication and the Community Sector, Final Report, ACOSS Paper No. 81, Australian Council of Social Services.(Accessed: 7 March 2001. http://www.acoss.org.au/papers/current.htm ).

Australian Bureau of Statistics (2004), 8119.0 Government Technology, Australia.

Australian Bureau of Statistics (2005), 8129.0 Business Use of Information Technology.

Barraket, John (2005), 'Online opportunities for civic engagement? An examination of Australian third sector organisations on the internet', in Australian journal of emerging technologies and society, $\mathrm{v}$ 3, no 1, online at: www.swin.edu.au/sbs/ajets/journal/issue4/pdf/AJETSV3N101Barraket.pdf .

Burt. R (2000) The network structure of social capital. Research in Organisational Behaviour. 22: 345423.

Burt, E. and J. Taylor (1999). Information and Communication Technologies: Reshaping the Voluntary Sector in the Information Age? Centre for the Study of Telematics and Governace, Glasgow Caledonian University. (Accessed 23 March 2002 http://www.brunel.ac.uk/research/virtsoc/reports/voluntarymain.htm).

Center for Excellence in Non-profits. February (1999). Wired For Good: A Joint Venture of the Center for Excellence in Non-profits and Smart Valley, Inc. (Accessed 15 May 2002 http://www.wiredforgood.org/survey/survey.html).

Centre for Community Networking Research (2003). The Monash Community Information and Communications Technology Index (CICT). School of Information Systems and Management, Monash University.

Coleman, J. (1988) Social capital in the creation of human capital. American Journal of Sociology. 94: S95S120.

Craig, B., Dashfield, B. and Thomson, T. (2003) Community Information and Communications Technology Research Project: Final Report. Victoria Link Limited.(Accessed 20 August 2004, http://www.ceg.govt.nz/initiatives/docs/cc-viclink-research.pdf ). 
Cukier, W. and Middleton, C. (2003) 'Evaluating the web presence of voluntary sector organisations: an assessment of Canadian Websites'. IT and Society. 1(3): 102-130 (Accessed 1 October 2004 http://www.stanford.edu/group/siqss/itandsociety/v01i03/v01i03a07.pdf ).

Denison, T. 'Community Sector Organisations: A Digital Divide in Communication and Knowledge Creation?' ITiRA: Information Technology in Regional Areas Conference. December 2003.

Dension, T., Stillman, L., and Johanson, G. 'The Australian non-profit sector and the challenges of ICT', First Monday, 12(5), 7 May 2007. (Accessed 22 September 2007 http://www.firstmonday.org/issues/issue12 5/matei/index.html ).

Department of Communications, Information Technology and the Arts (DCITA), 2005a. Information and communication technologies transforming the nonprofit sector: A discussion paper, Australian Federal Government.

Department of Communications, Information Technology and the Arts (DCITA), 2005b. The Role of ICT in Building Communities and Social Capital, Australian Federal Government.

Department of Communications, Information Technology and the Arts (DCITA), 2005c. Request for Tender No. DCON/05/169: Development of a possible model for a National Nonprofit ICT Coalition (NNIC).

Ekos Research Associates Inc. (2001). Survey of Voluntary Organisations, Final Report. Voluntary Sector Initiative: Canada. (Accessed 23/8/04, http://www.vsiisbc.ca/eng/imit/doc/technology_needs.doc $)$.

Granovetter, S. (1973) The Strength of Weak Ties. The American Journal of Sociology 78(6) 1360-1380.

Independent Sector and Cisco Systems (2001). Summary Report: Wired, Willing and Ready: Non-profit Human Service Organisations' Adoption of Information Technology, prepared by Princeton Survey Research Associates. (Accessed: 1 May 2002. http://www.independentsector.org/PDFs/WiredWillingReady.pdf ).

Jones, O., Conway, S. and Steward, F. (1999). Social Interaction and Organisational Change: An Analytical Review of Innovation Networks. Birmingham, UK: Aston Business School Research Institute. http://research.abs.aston.ac.uk/working papers/9934.PDF (Accessed 11/1/2005).

Kadushin, C. (2002) The motivational foundation of social networks. Social Networks. 24: 77-91.

Kendall, J. and Knapp, M. (1995) A loose and baggy monster: Boundaries, definitions and typologies. In J. D. Smith, C. Rochester and R. Hedley (eds.), An introduction to the voluntary sector, Routledge, London.

Kerr, G. (2002) Technology Needs of the Canadian Voluntary sector. Voluntary Sector Initiative: Canada.

Leverus (2001). Leveraging the Net: Association Internet Benchmarking Survey. (Accessed 23 August 2004, http://www.leverus.com/associationresourcecenter/library.cfm ).

Leverus (2003). Leverus Annual Internet Survey for Associations and Not-For-Profit Organisations: 2002. (Accessed 23 August 2004, http://www.leverus.com/associationresourcecenter/library.cfm ).

Lyons, M. (2001). Third Sector: the contribution of non-profit and co-operative enterprises in Australia. Allen and Unwin: Crows Nest, NSW.

Marks, P. (2006). 'Pentagon sets its sights on social networking websites', 6 June 2006, NewScientistTech. (Accessed 22 September 2007, http://technology.newscientist.com/article/mg19025556.200pentagon-sets-its-sights-on-social-networking-websites.html ).

Murray, V. and Harrison, Y. (2002) The Impact of Information and communications technology on volunteer management. Canadian Centre for Philanthropy. (Accessed 20 August 2004, http://www.merrillassociates.net/documents/pdf/impact_of_technology_canada.pdf ).

National Centre for Charitable Statistics (2004). (Accessed 24 January 2005, http://nccsdataweb.urban.org/ ). 
NCVO (2003). Developing the information and communications technology capacity of the voluntary and community sector. (Accessed March 242003 http://www.ncvo-vol.org.uk ).

O'Donnell, S. (1997). Irish voluntary, community and social movement organisations on the Internet. Paper presented to the Voluntary Action in Ireland North and South Conference, Trinity College Dublin, 16 May 1997. (Accessed 30 March 2003 http://models-research.ie/publications/art.html ).

O'Donnell, S. and Trench, B. (1999). Voluntary and community organisations in Ireland's 'information society'. Coleraine: University of Ulster, Association for Voluntary Action Research in Ireland. (Accessed 30 March 2003 http://models-research.ie/publications/art.html ).

O'Donnell, S. (2001) Towards an Inclusive Information Society in Europe: The Role of Voluntary Organisations. IST Study Models Research. (Accessed 1 October 2004 http://www.modelsresearch.ie/publications/vsrep.html ).

Pargmegiani, M. and Sachdeva, T. (2000) Information and public policy concerning voluntary sector use of information technologies, the Internet and the World Wide Web: An international report. Toronto: Canadian Centre for Philanthropy

Canadian Centre for Philanthropy (Accessed 1 July 2004 http://www.volnet.org/reports/english ).

PRA (2001). Information Management/Information Technology and the Voluntary Sector - Environmental Scan. Voluntary Sector Initiative: Canada. (Accessed 12 October 2004, http:// www.vsiisbc.ca/eng/joint tables/im_it/pdf/environmental_scan.pdf $)$.

Princeton Research Associates (2001). Summary Report: Wired, Willing and Ready: Non-profit Human Service Organisations' Adoption of Information Technology. Independent Sector and Cisco Systems, December. http://www.independentsector.org/PDFs/WiredWillingReady.pdf.

Schneider, J. (2003) 'Small, minority-based non-profits in the information age.' Non-profit Management and Leadership. 13(4) 383-399.

Steward, F. and Conway, S. (2000) Building Networks for Innovation Diffusion in Europe: Learning from the SPRINT Programme. in Enterprise and Innovation Management Studies. 1(3) 281-301.

Surman, M. (2001). From Access to Applications: How the Voluntary Sector is Using the Internet.(Accessed: 15 May 2002. http://www.volunteersonline.ca/news/environmentalscan.htm ).

TBC Research (2001). The Use of Information Technology in Non-Profit Making Organisations. TBC Research and Tate Bramald Ltd. (Accessed 1 Mar 2003, http://www.tateb.co.uk/site3/nfp/surveyresults.htm ).

Technology Affinity Group. (2003) Grantmakers Information Technology: Survey Report. Tachnology Affinity Group and Council on Foundations.

Ticher, P., Maison, A. and Jones, M. (2002) Leading the way to ICT success. Baring Foundation and Worshipful Company of Information Technologists. (Accessed 20 August 2004, http://www.baringfoundation.org.uk/ictwordversion.doc ).

VCOSS (1997). Bridges and Barriers Research Project, The Council of Adult Education for the Victorian Council of Social Services.(Accessed: 7 March 2001. http://www.skills.net.au/download/Bbrpt.doc )

Voluntary Sector Initiative (1999). Building on Strength: Improving Governance and Accountability in Canada's Voluntary Sector. Voluntary Sector Initiative: Canada.

Voluntary Sector Initiative (2002). Strengthening Voluntary Sector Capacity Through Technology: Report of the Joint Table on Information Management/Information Technology of the Voluntary Sector Initiative. Voluntary Sector Initiative: Canada.

W. K. Kellogg Foundation (2000). e-Philanthropy, Volunteerism, and Social Changemaking: A New Landscape of Resources, Issues and Opportunities. (Accessed 12 October 2004, http://www.wkkf.org/Documents/PhilVol/e-phil.pdf). 
W. K. Kellogg Foundation (2001). e-Philanthropy v2.001: From Entrepreneurial Adventure to an Online Community. (Accessed 24 March 2003 http://www.actknowledgeworks.net/ephil ).

Wellman, B. (1988). 'Structural analysis: from method and metaphor to theory and substance'. In Social structures : a network approach. In Wellman, B., and S. D. Berkowitz (eds). Cambridge [Cambridgeshire]; New York, Cambridge University Press: 19-61.

Williams, J. (1999) Survey Report on Selected Non-profits and Information Technology. United Way Community Services / University of Michigan School of Social Work. (Accessed 12 October 2004 http://comnet.org/graphics/comnet/uwcstechresults.pdf ).

Wyatt, J. (2001). E-enabling the Voluntary and Community sector. Office of the e-Envoy, UK. (Accessed: December 6 2001. http://www.e-envoy.gov.uk/publications/reports/e-enabling/summary.htm ).

Zelwietro, J. (1998) 'The politicisation of environmental organisations through the Internet.' Information Society, 14(1): 45-56. 